THE SOCIETY FOR THE PROMOTION

OF

HELLENIC STUDIES

REPORT FOR THE SESSION 1970-71 


\title{
THE SOCIETY FOR THE PROMOTION
}

OF

\author{
HELLENIC STUDIES
}

31-34 Gordon Square, London, WClH OPP

\section{REPORT FOR THE SESSION 1970-71}

Finance

The Society's accounts for 1970 close with a surplus of $£ 2,107$ in comparison with a surplus of $£ 4,032$ for 1969 . Income was $£ 453$ higher than in 1969 , but total expenditure increased by $£ 2,178$. The higher expenditure was mainly due to the larger size of the 1970 Journal, which cost (net) $£ 1,380$ more than last year. The production costs of Supplementary Paper No. 12, 'The Santorini Volcano and the Desolation of Minoan Crete' came to $£ 1,798$; this expenditure is carried forward as an asset of stock in hand in the balance sheet. The cost of Archaeological Reports was also higher, by £308; the library maintenance account was up by $£ 250$; printing, stationery and accounting were up by $£ 240$.

The favourable financial position maintained in spite of extra expenses was due to the following factors: the van Buren settlement provides a steady basic income which came to $£ 780$ in 1970; total receipts from the sale of current and back numbers of the Journal were $£ 1,626, £ 421$ more than in 1969 and the highest ever recorded; as the stock of back numbers is almost exhausted this total was only reached by the purchase and resale of several long runs of back numbers; generous grants, each of $£ 200$, were again received from the British Academy and the H. A. Thomas Fund of Cambridge University; the balance on deposit account remained high during the year, as did the Bank Rate, in consequence of which $£ 615$ deposit interest was received.

Increases in salaries, postage and printing are forecast, resulting in an estimated surplus for 1971 considerably reduced to approximately $£ 800$.

\section{Membership}

Membership figures as at December 31st, 1970 , are shown below, with comparable figures for past years.

$\begin{array}{lcccll} & \text { Members } & \begin{array}{c}\text { Life } \\ \text { Members }\end{array} & \begin{array}{c}\text { Student } \\ \text { Associates }\end{array} & \text { Libraries } & \text { Total } \\ 1966 & 1,188 & 196 & 160 & 676 & 2,220 \\ 1967 & 1,190 & 200 & 147 & 749 & 2,286 \\ 1968 & 1,208 & 195 & 130 & 780 & 2,313 \\ 1969 & 1,278 & 197 & 115 & 810 & 2,400 \\ 1970 & 1,327 & 196 & 104 & 845 & 2,472\end{array}$

\author{
Obituary \\ Miss J. E. Southan
}

The Hellenic Society, like the Roman Society and the Institute of Classical Studies, has suffered a severe loss in the sudden death, on April 6th from a virus infection, of Miss J. E. Southan. A graduate of the University of Manchester, she entered the Joint Library, as it was then called, as a junior assistant in 1939 and was appointed Librarian for both the Societies and the University of London in 1952 when the Institute of Classical Studies was founded. In this capacity she has taken the leading part in building the library up to its present strength. Among qualities which marked her office were clear mindedness, a grasp of essentials, robust commonsense, an exemplary neatness of routine and sympathy with visitors, enquirers and staff alike. Resolutely rejecting any idea of empire building she showed herself unafraid of hard work and long hours. There can be few members or visitors, whether from the old days in Bedford Square or more recently in Gordon Square, who will not call to mind immediately some act of personal kindness for which she was directly responsible.

The Council records with great regret the deaths of the following members:-

Professor Sir John Beazley, a Vice-President and M. S. Thompson, Hon. Treasurer from 1934 to 1950; also of: Miss E. Archibald; Miss I. Ashcroft; Professor E. Fraenkel; J. S. B. George; Dr G. van Hoorn; R. W. Hutchinson; Professor A. H. M. Jones; J. McDonald; Dr M. I. Machin; Miss G. H. A. Nash; R. M. Rattenbury; Professor L. R. Shero; G. A. D. Tait; Miss Lucy Talcott; and an honorary member, Professor A. W. Byvanck.

\section{Journal of Hellenic Studies}

Volume XC of the Journal was published in November but dispatch was delayed until early December by the late publication of Archaeological Reports. The volume was 100 pages longer than the 1969 Journal, thanks to the increased funds available, and the backlog of material has now been eradicated. As the last full Index of the Journal was published in Volume LXI, 1941, arrangements have now 
been made for the indexing of Volumes LXI to $\mathrm{XC}$.

The Archaeological Reports were published in early December. Financial support was again received from the British School at Athens. Sales throughout the year continued at a satisfactory rate.

Supplementary Paper No. 12: The Lord Northcliffe Lectures, given by Professor Denys Page at University College London, were published in November as a new Supplementary Paper under the title 'The Santorini Volcano and the Desolation of Minoan Crete'. It is selling steadily at $£ 1 \cdot 20$ plus postage.

\section{Administration}

Professor K. J. Dover, F.B.A., was nominated for election as President of the Society for the period 1971-1974.

The ten members of Council who retire in rotation under Rule 19 are: Miss S. A. Barlow, Dr D. R. Dicks, R. V. Nicholls, Dr D. M. Nicol, C. A. Rodewald, Dr T. J. Saunders, J. Sharwood-Smith, Dr P. Walcot, Professor M. M. Willcock, N. G. Wilson.

In their place the Council have nominated the following for election: D. Blackman, J. Boardman, Dr L. Brandwood, R. W. B. Burton, Dr M. A. R. Colledge, A. Garvie, Miss R. Harriott, Professor G. S. Kirk, J. D. Smart, Dr H. J. K. Usher.

Once again the Society Council wish to convey their thanks to Messrs Davey, Bridgwater \& Co. and particularly to $\mathrm{Mr}$ Betts, for acting as Honorary Auditors to the Society's accounts.

\section{Meetings}

The following communications have been made at Meetings of the Society during the Session:-

November 12th, 1970, Dr J. P. Barron on 'New Light on Old Walls: the Frescoes of the Theseum.'

January 7th, 1971, Dr A. A. Long on 'Dialectic and the Stoic Sage'.

March 18th, 1971, Dr A. J. Graham on 'The Pattern of Early Greek Colonization'.

June 3rd, 1971, Professor R. Browning on 'Homer in Byzantium'.

\section{Joint Meetings}

Meetings were arranged in collaboration with local associations during the Session 1969-70:-

At London: $\mathrm{Mr}$ D. M. MacDowell on

'Men and Animals in Aristophanes'.

At Nottingham: Mr D. J. Blackman on

'Ancient Greek Harbours'.

At Leeds: Mr J. N. Coldstream on 'The Minoan Eruption of Thera'.

At Liverpool: Dr T. T. B. Ryder on
'Leadership in a Democracy: three great Athenians'.

At Southampton: Mr D. A. Campbell on

'Greek Lyrics and their Music'.

At Durham: Dr S. A. Barlow on 'Solo

Arias and Lyric Dialogue in Greek Tragedy'.

At Keele: Professor A. D. Fitton Brown on 'Morality and Character in Antigone'.

At Manchester: Dr J. B. Hainsworth on

'The Criticism of an oral Homer'.

At Cardiff: Dr J. P. Barron on 'Finding a lost Epic: the "Deeds of Theseus"'

At Exeter: Mrs S. C. Humphreys on 'Anthropology and the Classics'.

At Aberystwyth: Professor W. G. Arnott on 'Schliemann, Troy and Mycenae'.

At Hull: $\mathrm{Mr}$ J. N. Coldstream on 'The Minoan Eruption of Thera'.

At Edinburgh: Professor R. P. WinningtonIngram on 'Music in Ancient Greek Life'.

At Sheffield: Professor J. F. Healy on 'Greek electrum coin series'.

\section{Joint Library}

The Library had another busy and crowded year. Since any kind of expansion does not at present appear feasible, it seems best to concentrate on providing the most efficient possible service to readers within the limitations of the existing staff and space.

5,221 books were borrowed by 763 members during the year. (Last year's figures were 5,528 books borrowed by 719 members). 265 parcels of books were sent by post, 1,377 xerox copies were made by the Library staff, mostly for other Libraries, since readers in the Library are asked to do their own copying.

1,032 books were added to the Library620 by the Joint Library and 412 by the Institute. 367 periodicals are currently taken, 270 by the Joint Library (including 194 by exchange) and 97 by the Institute (including 59 by exchange).

360 books were bound (213 by the Joint Library and 147 by the Institute) and 153 periodicals ( 110 by the Joint Library and 43 by the Institute.)

Thanks are due to the following for gifts to the Library: Dr R. D. Barnett, Professor M. Bieber, Dr G. Biegel, Professor G. Bozonis, Professor I. A. F. Bruce, Professor W. M. Calder III, Professor J. L. Caskey, Miss E. Clay, Mr B. F. Cook, Dr Ch, Doumas, Dr V. L. Ehrenberg, $\mathrm{Mr}$ D. Elkington, Dr J. Fitz, Professor K. A. Garbrah, Mr P. S. Georgioudakis, Dr W. Gerressen, Dr M. Grant, Mr J. Hansman, Professor C. H. E. Haspels, Mr H. Hodges, Mrs S. C. Humphreys, Miss C. Jeannoulides, Mr K. D. Kalokyris, Professor M. Kokolakis, Mr X. A. Kokolis, Mr G. M. Lee, Dr A. A. Long, Mr J. G. Macnamara, Dr Rolf Meyer, Professor A. D. Momigliano, Mr A. N. Papageorgiou-Venetas, Mr A. L. F. 
Rivet, Mr J. Schulman, Dr R. F. Rossi, Dr R. Hope Simpson, Professor O. Skutsch, Professor D. E. Strong, Mr and Mrs A. Stylianou, Dr V. Sussman, Professor A. D. Trendall, Professor E. G. Turner, Mr K. A. Varouskos, Mr K. D. White, Professor R. P. Winnington-Ingram, Professor K. Ziegler, Comité National Hellénique de l'Association Internationale des Etudes du Sud-Est Européen, National Bank of Greece, Royal Greek Embassy, School of Oriental and African Studies, University of Cincinnati Dept. of Classics, Warburg Institute.

\section{The Slides Collection}

During the year the slides collection was extensively used, and the duplication of slides increased, mainly owing to a large order from the University of Ottawa, Canada.
The number of individual slides borrowed was 2,020 . The 51 sets of slides also hired brought the total number to 4,315 , about 1,600 fewer than in 1969. The number of slides sold was 6,201 (4,177 in 1969). The collection of coloured slides now contains 1,519 Greek slides and 2,034 Roman slides. Dr F. H. Stubbings has kindly offered, as a gift to the Hellenic Society, reproductions of $\mathrm{Mr}$ Piet de Jong's coloured drawings of Mycenaen pottery. It is hoped to place these slides in the collection early in 1971.

Two new sets of slides were added to the collection-a coloured set of 'Gallia Narbonensis-the Greek sites', by $\mathrm{Mr}$ A. L. F. Rivet, of Keele University, and a black and white set on 'The Trojan Horse in Classical Art', by Dr B. A. Sparkes, of Southampton University. 


\section{LIST OF MEMBERS}

\section{Elected during the session 1970-71}

Abdelnour, H., Institut Francais d'Archéologie, Beyrouth, Liban.

Ahmet, E., 2 Sefton Street, London, S.W.15.

Arazm, Mrs D., 30 Ambleside Gardens, Wembley, Middlesex.

Ayres, J., 137 Leam Terrace, Leamington Spa, Warwickshire.

Baerentzen, H., Dalgas Boulevard 87, 2000 Copenhagen-F, Denmark.

Ball, R., Wadham College, Oxford.

Booth, Miss A., Flat 3, 19 Chalcot Square, London ,N.W.1.

Bruce-Milne, Mrs M., 3 Temple Gardens, Temple, London, E.C.4.

Calame, C., 86 Avenue de la Sallaz, CH-1010 Lausanne, Switzerland.

Calhoun, S. L., 2426 E. Alamos Avenue, Fresno, California 93726, U.S.A.

Chapman, N., 15 Upton Close, Park Street, St Albans, Hertfordshire.

Chi, Professor Dong-shik, 17-7 Nogbun Dong, Sohdaemoo Ku, Seoul, Korea.

Coles, Mrs E. I., 4 Guildhouse Street, London, S.W.1.

Comber, M. R., 17 Lampard Grove, London, $N 166$ XA.

Day, W. K., 1182 Market Street, San Francisco, 2, U.S.A.

Demakopoulos, Dr S. A., 600 West 178th Street, New York, N.Y. 10033, U.S.A.

Dragona-Monachou, Mrs M., Crosby Hall, Cheyne Walk, London, S.W.3.

Epstein, Miss A. W., 18 White House Way, Solihull, Warwickshire.

Evans, D. E., 44 Daisy Bank Crescent, Walsall, Staffordshire.

Fotina, Mrs M., 1A Kidderpore Avenue, Hampstead, London, N.W.3.

Fujisawa, Professor N., 10-8 Icchodacho, Matsugasaki, Sakyoku, Kyoto, Japan.

Garland, R. S. J., 4 A Sunningfields Crescent, Hendon, London, N.W.4.

Gellie, Professor G. H., University of Melbourne, Parkville 3052, Victoria, Australia.

Grace, Miss E., Apt. 141, Novopeschanaya 23, Moscow A 252, U.S.S.R.

Grant, Miss M. J., William Goodenough House, Mecklenburgh Square, London, W.C.1.

Grenham, D., 40 Elderton Road, Westcliff-on-Sea, Essex.

Guillen, F. L., Avenida de la Monclod 7, Madrid-3, Spain.

Hackenberg, M. R., University of Cincinnati, Ohio 45221, U.S.A.

Hadji-Nicolaou, D., 5 Rainville Road, London, W.6.

Haydock, K., Seattle Preparatory School, 240011 th Ave.E., Seattle, Washington 98102, U.S.A.

Hayes, W., Cluny Lodge, Sandown Avenue, Esher, Surrey.

Hoddinott, Mrs B., Woodstock House, Woodstock Road, Bedford Park, London W.4.

Hodgson, Mrs P., Rohan, Hatherley Road, Kew, Surrey.

Holum, K. G., 8132 West Beach Drive, N.W., Washington, D.C. 20012, U.S.A.

Hubbard, R. B., 30 Hampstead Grove, London N.W.3.

Humberstone, R. D., 51 Harrington Gardens, London, S.W.7.

Kapetanopoulos, Professor E., Central Connecticut State College, New Britain, Connecticut 06050 , U.S.A.

Kapoor, Mrs J. G., 5755 Mt Creek Road N.E., Atlanta, Georgia 30328, U.S.A.

Knox, O. A., $38 B$ Linden Gardens, London W.2.

Kofos, E., Royal Greek Embassy, 51 Upper Brook Street, London W.1.

Lee, Miss J., 17 Streatham Court, Streatham High Street, London, S.W.16.

Lloyd, A. B., University College, Swansea, Glamorganshire, Wales.

Mansfield, Professor B., Macquarie University, North Ryde, N.S.W. 2113, Australia.

Markianos, Dr S., Athens College, P.O. Box 175, Athens, Greece.

McKibben, Mrs K. A., 1111 N.McLean, Bloomington, Illinois 61701, U.S.A.

Menzilcioglu, Miss I., 9 Ryfold Road, Wimbledon Park, London, S.W.19.

Mills, R. L., Aramstone, Kings Caple, Hereford.

Neale, I. S., 6 Hill Field, Selby, Yorkshire.

Nunes, Mrs H., Falkner House, 19 Brechin Place, London, S.W.7.

Oliver-Smith, P., Rice University, Houston, Texas, 77001, U.S.A.

Oppenheim, J. R., 42 Northumberland Road, New Barnet, Hertfordshire.

Phillips, A. C., Athinai, Hill Crest, Est., Helston, Cornwall.

Phillips, Miss S. D., 26 Lower Grove Road, Havant, Hampshire.

Pindborg, Professor J. J., The Royal Dental College, 4 Universitetsparken, DK-2100 Copenhagen, Denmark.

Postlethwaite, N., The University, Leicester.

Preiser, Professor Dr W., 6 Frankfurt am Main, Mechtildstraése 10, Germany. 
Quigley, The Rev S., 15 Dalymount, Dublin 7, Eire.

Ridley, R. E., 589 Etruria Road, Basford, Stoke-on-Trent, Staffordshire.

Rutter, Dr N. K., University of Liverpool, Liverpool 17.

Sargent, A. C., 4 Walnut Tree Close, Guildford, Surrey.

Schaps, D. M., 9 Banks Street, Cambridge, Massachusetts 02138, U.S.A.

Schreiner, J. H., Sorbyhaugen 16, Oslo 3, Norway.

Slade, P., 55 Moorfield Road, Crosby, Liverpool L23 9 UB.

Sourvinou, Miss C., St Hilda's College, Oxford.

Spence, Miss Y., 26 A Scarsdale Villas, Kensington, London, W.8.

Steeghs, J. A. M. G., Hoogheem 409, Boxtel, Netherlands.

Sullivan, J. P., 127 W Oakwood Place, Buffalo, N.Y. 14214, U.S.A.

Sussman, V., 12 Gainsborough Gardens, London, N.W.11.

Thomas, J., 257 Yardley Wood Road, Moseley, Birmingham 13.

Threatte, Professor L., University of California, Berkeley, California 94720, U.S.A.

Trimble, D., Light Horse Court, Royal Hospital, Chelsea, London, S.W.3.

Vagnetti, Miss L., Via Monte Zebio 25, 00195 Rome, Italy.

Vaux, A. J., Visual Publications Ltd., 197 Kensington High Street, London, W.8.

Vessey, Dr W. T. C., Queen Mary College, Mile End Road, London, E.1.

Walls, J. W., 142 Lark Avenue, San Antonio, Texas 78228, U.S.A.

Warner, Miss K., Rollrights, Lymington Road, Milford-on-Sea, Hampshire.

Watson, Professor, W., Percival David Foundation of Chinese Art, 53 Gordon Square, London, W.C.1.

Webb, R. B., 29 St Helena Road, Colchester, Essex.

Whitford, R., 29 Cherry Tree Road, East Finchley, London, N.2.

Wilkinson, Miss K., 9 Wordsworth Court, Lovelace Road, Surbiton, Surrey.

Yatromanolakis, G., 16 Belsize Park, London, N.W.3.

Young, A. M., Peter Robinson College, Peterborough, Ontario, Canada.

\section{STUDENT ASSOCIATES}

Atkins, R., University College, London.

Bertram, Miss A., Newnham College, Cambridge.

Bowden, Miss J., University of Manchester.

Brown, Mrs E. C. E., Extramural Department, London University.

Bulwer, J. W., Keble College, Oxford.

Cann, N. J., Merton College, Oxford.

Cartledge, P. A., University College, Oxford.

Castle, B., University College, London.

Chant, Miss D., Royal Holloway College, London.

Chapman, J. C., Institute of Archaeology, London.

Christodoulou, G. A., Trinity College, Cambridge.

Davenport, Mrs E., University of Edinburgh.

Dickinson, Miss K. M., University of Manchester.

Driscoll, R. D., King's College, London.

Feneron, J., University College, London.

Gibbons, Miss S. E., Bedford College, London.

Heal, Miss S., St Aidan's College, Durham.

Holker, Miss A. B., Bedford College, London.

House, G. A. L., Courtauld Institute of Art, London.

Indoe, D., Hertford College, Oxford.

Katz, J. B. H., Pembroke College, Oxford.

Kitching, Miss J., Westfield College, London.

Laity, Miss A. H., University College, London.

Lancelot, J. B., King's College, Cambridge.

Maccabe, J., Magdalen College, Oxford.

Markantonatos, G., University of Southampton.

Marley, P., Lincoln College, Oxford.

Mason, P. G., Jesus College, Oxford.

Nicholson, Miss J., University of Birmingham.

Parsons, R. J. S., St Catharine's College, Cambridge.

Patriarchea, Miss F., Bedford College, London.

Richardson, Miss D. J., King's College, London. 
Rutter, Miss A., King's College, London.

Sackman, S., Pembroke College, Oxford.

Stuart, Miss A. J., King's College, London.

Swaddling, Miss J., University College, London.

Tamvakis, Miss A., Lady Margaret Hall, Oxford.

Wells, Miss B. M., Bedford College, London.

Woodhams, J. B., St Catharine's College, Cambridge.

Wright, G. A., University of Bristol.

Yeadon, Miss S. A., University College, London.

\section{SUBSCRIBING LIBRARIES}

Brazil, Nucleo de Documentacao, Caixa Postal 1050, Niteroi, Rio de Janeiro.

LEBANON, Central Library, Beirut Arab University, Beirut.

U.A.R., Central Library, Cairo University, Giza, Egypt.

U.S.A., California, Humboldt State College, Arcata.

U.S.A., California, Art Department, San Jose State College, San Jose.

U.S.A., Illinois, McCormick Theological Seminary, West Belden Avenue, Chicago.

U.S.A., Illinois, Illinois State University Library, Normal.

U.S.A., Indiana, Indiana State University Library, Evansville.

U.S.A., Massachusetts, Hilles Library, Radcliffe College, Cambridge.

U.S.A., New Jersey, Camden Library, Rutgers University, Camden.

U.S.A., New York, New York State University College, New Paltz.

U.S.A., Ohio, Wright State University Library, Dayton.

U.S.A., Pennsylvania, Hamilton Library, Edinboro State College, Edinboro.

U.S.A., South Carolina, Dacus Library, Winthrop College, Rock Hill.

U.S.A., Texas, Cody Memorial Library, Southwestern University, Georgetown.

U.S.A., Virginia, James Branch Cabell Library, Virginia Comm. University, Richmond.

U.S.A., Washington, Eastern Washington State College Library, Cheney.

U.S.A., Wisconsin, Robert L. Pierce Library, Stout State University, Menomonie. 


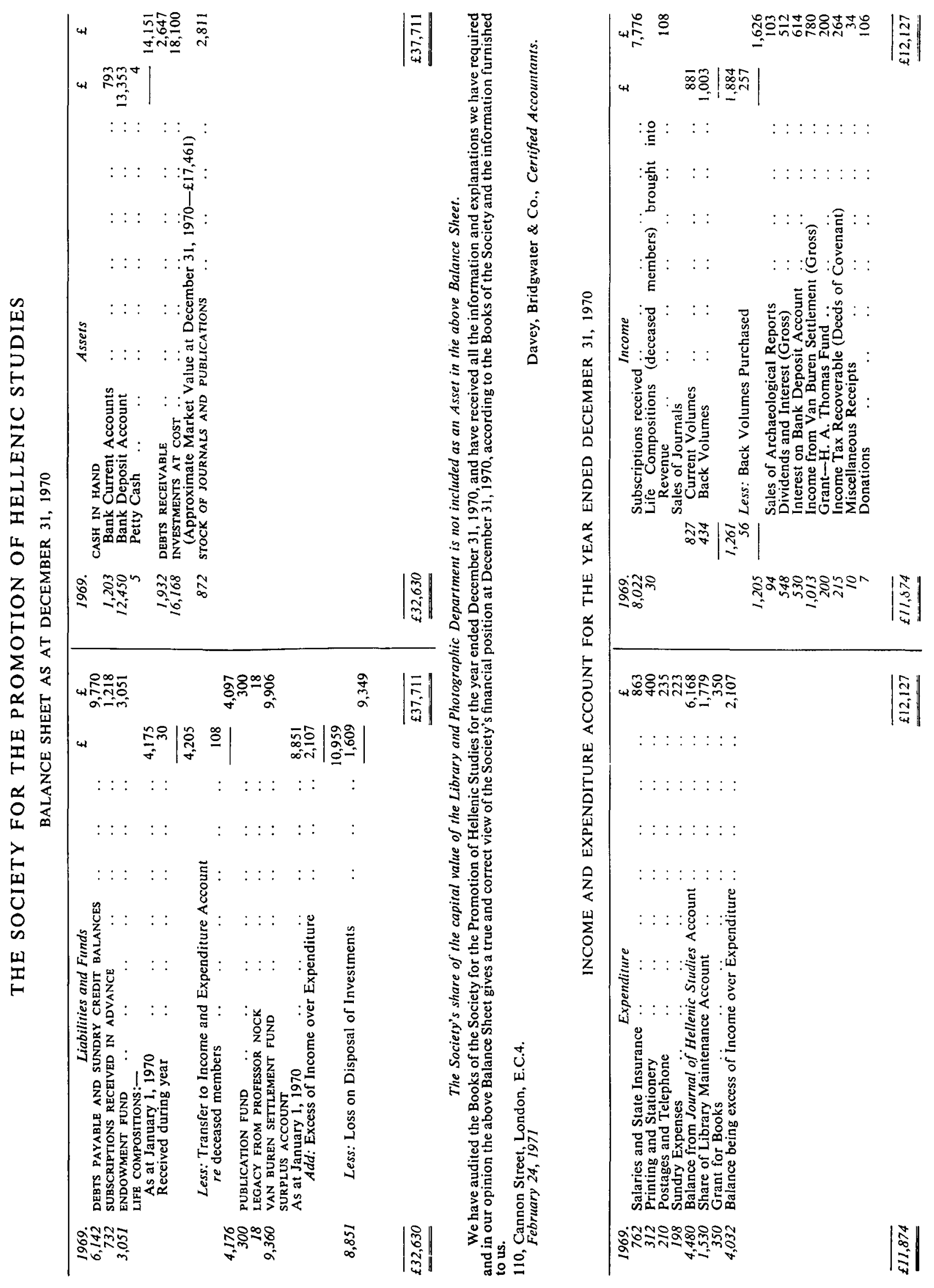



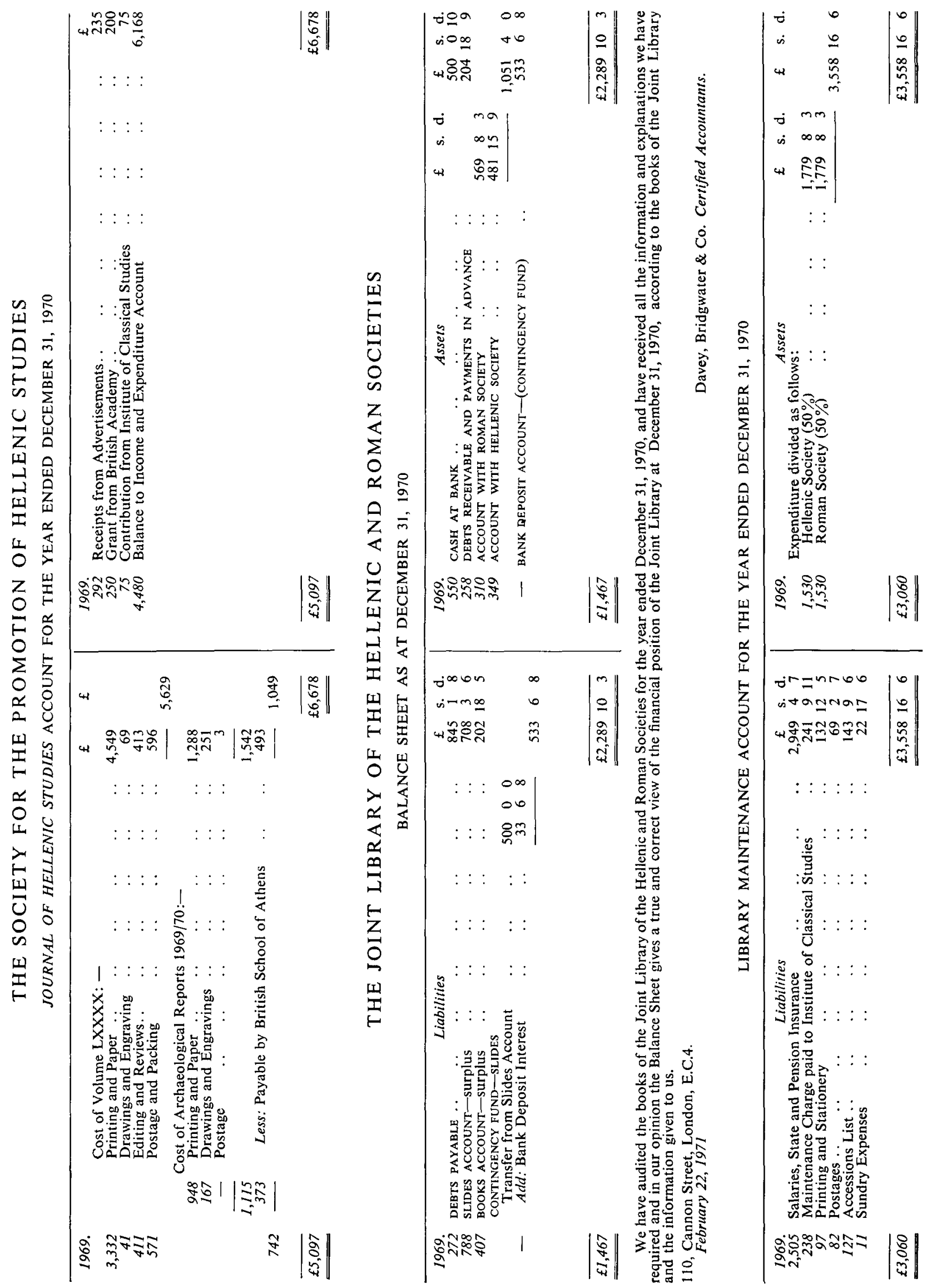

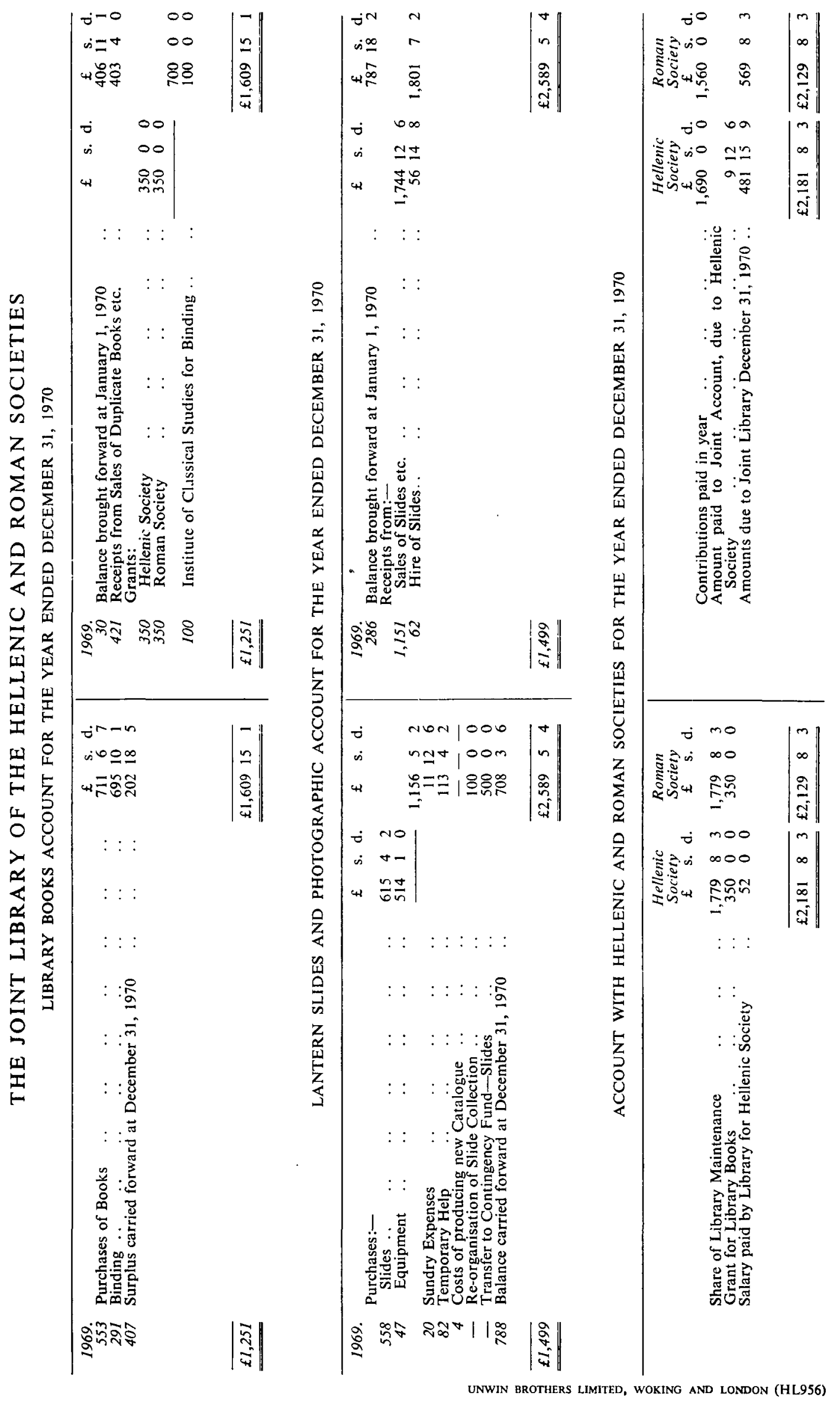


\title{
THE SOCIETY FOR THE PROMOTION OF HELLENIC STUDIES
}

\author{
31-34 Gordon SQuare, London, W.C.I.
}

\section{HONOPARY MEMBERS}

H.M. the King of Sweden.

Ákurgal, Proí. Z., Dil Tarin Fakultesi, Ankara Universitesi, Ankara, Tutrkey.

Amandry, Prof. Pierre, Ecole franşaise, Didotou 6, Athens, Greecs.

Blegen, Prof. C. W., 9, Plutarch Street, Athens, Greece.

Chantraine, Prof. Pierre, $3^{8}$ bis rue Boulard, Paris XIV', France.

Cherniss, Prof. H., Institute for Advanced Study, Princeton, New Jersey, U.S.A.

Daux, Prof. G., 6 Avenue Paul Appell, Paris XIVe, France.

Dinsmoor, Prof. W. B., American School of Classical Studies, Athens, Greece.

Dow, Prof. S., Widener Library, 69o, Cambridge 38, Mass., U.S.A.

Festugière, A.-J., O.P., 222, Rus du Faubourg Saint-Honord, Paris VIIIe, France.

Haspels, Prof. C. H. E., Archaeologisch Instituth, 33 Weesperzijde, Amsterdan, Holland.

Johansen, Prof. K. F., The University, Copenhagen, Denmark.

Karouzou, Mrs. S. P., National Museum, Athens, Greece.

Klaffenbach, Dr. G., Deutsche Akademie der Wissenschaften zu Berlin, (East). Germany.

Kunze, Dr. E., 8021 Grosshesselohe bei München Immergrünstrasse 1, Germany.

Larsen, Prof. J. A. O., University of Missouri, Columbia, U.S.A.

Lesky, Prof. Albin, Alserstrasse 69/1 7 , Vienna 8, Austria.

Marinatos, Prof. S., Polyla Street 47, Athens, Greece.

Matz, Prof. Friedrich, Archäologisches Seminar der Universität Marburg, 355 Marburg/Lahn, Germany.

Meritt, Prof. B. D., Institute for Adranced Studies, Princeton, New Jersey, U.S.A.

Orlandos, Prof. A. C., Navarinou Street, 6, Athens, Greece.

Pfeiffer, Prof. R., Hiltenspergerstrasse 21/0, Munich 13, Germany.

Platon, Dr. N., The Acropolis Museum, Athens, Greece.

Richter, Dr. G. M. A., 81 Viale delle Mura Gianicolensi, Rome, Italy.

Robert, Prof. L., 31 Avenue Parc de Montsouris, Paris XIV', France.

Romilly, Prof. J. de, $3^{8}$ rue Guynemer, Paris VIe, France.

Schaeffer, Dr. C. F. A., Le Castel Blane, 14 Rue Turgot, St. Germain-en-Laye, France.

Snell, Prof. Bruno, Universität, Hamburg, Germany.

Strasburger, Prof. H., Urachstrasse 37,78 Freiburg, Germany.

Thompson, Prof. Homer A., Institute for Advanced Studies, Princeton, New Jersey, U.S.A.

White, Prof. Mary E., Trinity College, Toronto 5, Canada.

Youtie, Prof. H. C., University of Michigan, Ann Arbor, U.S.A.

Zancani Montuoro, Signora P., Il Pizzo, S. Agnello di Sorrento, prov. Napoli, Italy.

Ziegler, Prof. Konrat, Herzberger Landstrasse 70, $20 b$ Göttingen, Germany. 


\section{The Society for the Promotion of Hellenic Studies}

31-34 Gordon Square, LONDON, WCrH opP

President: Professor K. J. DOVER, F.B.A.

The Society, founded in 1879 to advacce the study of Greek language. literature, history and art, maintains conjointly with the Society for the Promotion of Roman Studies and in association with the Institute of Classical Studies of the University of London

I. A Library of some 42,000 volumes, containing many costly works and rare periodicals.

2. Some 15,000 lantern slides covering the whole domain of ancient life and art. Besides the general collection, there aro sets of alides with 2. Some 15,000 lant
lecture texts.

Books and slides can be sent to Members by post. Commuaications about books and slides should be addressed to the Librarian at the above address.

Four general meetings, with lectures, are held in London annually, and there are other meetings in different parts of the country.

Subscribers receive free the Society's two annual publications: The Journal of Hellenic Studies, one of the foremost British periodicals in the

field of Greek scholarship, contalning articles, illustrations and book reviews: Archaecological Roports, a fully illustrated account of fresb discoveries in Greece and Greek lands, with bülletins announcing important new acquisitions by museums in Britain.

These two periodicals are on sale to the general public at $f_{4.50}$ and $£_{0.63}$ respectively.

The annual subscription to the Society is $\varepsilon_{3}$. The Composition fee for life-membership is $\varepsilon_{15}$ for those over 65 years of age, after 5 years membership The subscription for Libraries and Student Associates is $£_{4} .63$ and $\ell_{x}-50$ respectively. There is no entrance fee.

Applications for mombership or mquiries about the Society should be addressed to the Secretary. Telephone or -3877493

\section{The Society for the Promotion oi P: san Studies}

\section{1-34 GORDON SQUARE, LONDON, WCIH OPP}

President: DR. A. IT a.munaly, F.B.A.

The Society was formed in r 910 to promote the study of the archaeology, art, literature, and history of Italy and the Roman Empire down to about the year A.D. 700, by publishing journals, forning a library, and holding meetings.

The Journal of Roman Studies is published annually and contains articles written by leading British and foreign scholars and reviews of recent publications. It is abundantly illustrated. The Society also publishes Britannia, devoted to Romano-British and connected studies, to which the annual survey of Romano-British excavations, previously published in the Jowrnal is now transferred. The survey continues to be available as an offprint.

The Society maintains, in conjunction with the Hellenic Society, a joint library of works on classical antíquity and a colloction of lantern slides. Members are entitled to borrow books and slides, which can be sent to them by post, and may also consult books in the library of the Lundon University Institute of Classical Studies, which is complementary to that of the Societies.

The annual subscription is $f_{3}$ which entitles members to one of the journals, or $£ 5.50$ for both. Institutions, except schools, pay the full rate for the two. Life membership for those of 65 or over $f_{15}$. Student-associates $f_{1}$.50. Non-members $f_{4}$ for each journal.

All inquiries should be addressed to the Secretary. or-387-8 I 57 .

The following may be obtained from International Untversity Booksellers, 39 Store Street, W.C.1.

1. LIST OF THE WRITINGS OF J. D. BEAZLEY. Oxford. 1951. Price 15.

2. Supplementary Papers:

No. II ECCLESIASTICAL SITES IN ISAURIA (CILICIA TRACHEA By A. C. Headlam. Folio. 1893. Prico f0.55

No. VI CORINNA

By D. L. Page. 88 pages. Demy 8vo. Reprint. Price $£ 0.63$

No. VII PERSPECTTVE IN ANCIENT DRAWING AND PAINTING

By John White. 100 pages. Demy 8vo.

No. IX THB GREEK ANTHOLOGY: SOURCES AND ASCRIPTIONS

By A. S. F. Gow. 62 pages. Demy 8 vo. Prico £0.48.

No. $X \quad$ ISLAND GEMS 170 pages. 20 plates. Demy 8 vo. Prico $£ 1.50$

No. XI EURIPIDES AND THE JUDGEMENT OF PARIS

By T. C. W. Stinton. 80 pages. 8 plates. Demy 8vo. Price 80.87 .

No. XII THE SANTORINI VOLCANO AND THE DESOLATION OF MINOAN CRETE

by D. L. Page 45 pages. 20 plates. Crown 4 to. Price f1.20.

Note: Supplementary Papers I, III, IV, V and VIII are out of print.

\section{THE CLASSICAL ASSOCIATION}

The maln aims of the Classical Association are to promote and sustain interest in classical studies, to maintain their rightful position in universities and schoois, and to give scholars and teachers opportunities of mecting and discussing their problems. It organizes an annual conference, lasting four or five days, In a university centre, and sponsors thirty-one branches, most of which hold Greek and Latin Reading Competitiona for Schools. Its activities are fully reported in its annual Proceedings, issued free to all members.

The present membership of the Association is approximately 4,500. Membership is open both to individuals and to institutions at an annual subscription of 25p. (Life composition for individual members (5.25). Members may obtain the Classical Revieve and Classical Ouarterly at reduced prices (Review, £2.25; Quarterly, £2.00; combined subscription £3.871). Greece and Rome may also be obtained through the Association for an annual subscription of $f_{1.50}$. Applications for membership and subscriptions for the fournals (which should normally be received by January 3 Ist in each year) should be addressed to the Hon. Treasurer, Professor L. A. Moritz, University College, Cardiff.

The Association can also supply copies of the Index to the First Series of the Classical Review (price $€ \mathbf{1} .25$ for members, $€ \mathbf{r}$.50 for non-members post free) and of the last two issues of The Year's Work in Classical Studies, covering the years $1939-45$ and $\times 945-7$ (price fo.30 each volume, post free). These publications and details of the various occasional publications of the Association, including all Supplements to Greece and Rome, are obtainable from the Hon. Treasurer or from Mr. R. G. Tetstall, University College, Cardiff. Inquiries should be sent to either of the Hion.

Secretaries (Dr. J. G. Landels, The University, Whiteknights Park, Reading, and Miss E. M. Tucker, ro Freeland Road, London W.5.)

Contributions to the JOURNAL should be sent to Dr. B. Sparkes, The University, Southampton, S09 5 NH. Books intended for review should be addressed to The Librarian, Hellenic Society, 31-34 Gordon Square, London, WC1H OPP 